\title{
A BRUSSELS WINDOW ON THE DIVERSITY OF LANGUAGES IN EUROPE
}

\author{
CAMIEL HAMANS
}

\section{Introduction}

In constitutional terms the European Union (EU) is a hybrid international organisation. In some respects the EU should be called a confederation, but according to other constitutional criteria it looks more like a federation. Therefore the EU is often called an organisation sui generis (Schütze 2012: 121-148 ${ }^{1}$ ). This special constitutional nature implies that that the competences of the EU are not immediately clear either. What the competences of the EU are is described in the Consolidated Treaty of the Functioning of the European Union, which is the Treaty of Maastricht (1992) as amended by the later Treaties of Amsterdam (1997), Nice (2001) and Lisbon (2007) and the accession treaties of 1994, 2003 and 2005. ${ }^{2}$

The mean feature of article 4 of title 1of part 1 of this Consolidated Treaty is that all competences that are not conferred upon the Union remain with the member states. In some areas such as customs, competition, marine biological resources and monetary policy when it comes to the Euro, the EU has exclusive competence. In areas such as internal market, transport, environment, freedom, security and justice the member states and the EU share competences. In other areas the actions of the Union only may support, coordinate or supplement actions of the member states. Culture, education and vocational training belong to this final and minimal part of the EU competences.

\footnotetext{
${ }^{1}$ For a different view see Eijsbouts 2006.

${ }^{2}$ The full text of this treaty can be found at www. consilium.europa.eu/documents/treaty-oflisbon?lang=en
} 
This implies that there is not a common European language policy. There are national language policies in certain European countries, some of them member states of the EU and others not. In so far as the EU is engaged in language policy this policy must be complementary to the policy of the member states. Therefore the main activities of the EU with respect to languages had to do with second or foreign language learning.

Recently the EU became more active in the area of languages and language policy. This is because the Charter of Fundamental Rights of the EU, adopted in 2000, is included in the Treaty of Lisbon. Consequently the Charter now has become legally binding. Article 22 of this Charter places an obligation on the Union to respect linguistic diversity and prohibits discrimination on grounds of language according to article $21^{3}$.

However, it is not the EU that is most active in the area of language policy. The Council of Europe is the institution which seriously monitors the diversity of languages in Europe and especially the situation of regional and minority languages.

Since the difference between these two institutions and their competences is not very well known a short overview of the history of the European cooperation and integration may be useful. The history explains why there are two different institutions and also makes clear what the different areas are in which the two institutions have a certain competence.

\section{Brussels Window}

\section{Very short history of the European cooperation and integration}

19 September 1946 the former prime minister of the UK, sir Winston Churchill, addressed the students and the staff of the University of Zürich (Switzerland $)^{4}$. In this speech Sir Winston spoke about 'the tragedy of Europe' and give his opinion about the future of Europe: "We must all turn our backs upon the horrors of the past. We must look to the future. (...) We must build a kind of United States of Europe (...) The first step in the re-creation of the European Family must be a partnership between France and German. (...) And the first practical step would be to form a Council of Europe." Actually Sir Winston Churchill suggested to build a European Federation - without the UK, since the UK was part of its own British Commonwealth of Nations - according to the model of the Swiss Federation. His ideas were in line with the pre-Second World

\footnotetext{
${ }^{3}$ For a recent overview of the language policy of the EU see the Fact Sheets on the European Union, Sectoral Policies 5.13.6.

${ }^{4}$ For the ful text see: w w.europarl.europa.eu/brussels/website/media/Basis/Geschichte/bis 1950/Pdf/Churchill_Rede_Zuerich.pdf
} 
War idealistic pan-Europe movement lead by the Hungarian diplomat Count Coudenhove-Kalergi.

Churchill's appeal was followed by a huge conference under his own presidency in The Hague in 1948, attended by more than 1000 participants from more than twenty countries, which resulted in the foundation of the Council of Europe by the Treaty of London (1949).The first achievement of this Strasbourg based international organisation was the European Convention on Human Rights, adopted in 1950. According to the Convention a European Court of Human Rights was established in Strasbourg in 1959.

These first steps have determined the route the Council followed. Nowadays, with 47 member states, the Council of Europe is mainly active in the areas of democracy, human rights and state of law. Among the member states one finds all the members of the EU but also Russia, Georgia, Ukraine, Liechtenstein, Iceland and Vatican ${ }^{5}$.

Whereas the initiative of Sir Winston Churchill and its elaboration may be seen as more or less following the idealistic path sketched by the pan-European movement from the interwar period, a more practical and often called more functional path was chosen by the French diplomat and federalist Jean Monnet and his compatriot the minister of foreign affairs and former prime minister Robert Schuman ${ }^{6}$.

In his famous address to the French Assemblée nationale on 9 May 1950 the so called Schuman declaration - Schuman suggested a policy of small steps. His aim was to achieve permanent peace in Europe via economic means. In the past France and Germany started several wars because each of them aimed at economic and thus political supremacy in Europe. The idea of Schuman was to combine and integrate economies of both, and hopefully more European countries, as to prevent future wars. The hope was that an integration of national economies would lead to future social and political cooperation and integration. The first step was to put the French, German and possibly other countries' coalmines and steelworks under a common High Authority, which was a completely new idea of supranational cooperation instead of an intergovernmental ${ }^{7}$. The Schuman declaration was welcomed in many European countries and lead in 1951 to the Treaty of Paris, which initiated the founding of the European Coal

\footnotetext{
${ }^{5}$ For more information about the Council of Europe-Conseil de l'Europe and its history see: www.coe.int. Also: Van Meurs a.o (2013: 30-43).

${ }^{6}$ Robert Schuman was the best person to suggest German-French cooperation, since he coming from Lorraine fought as an officer in the German army during World War I and as a French officer during World War II (Teasdale \& Bainbridge 2012 ${ }^{4}$ : 719-721).

${ }^{7}$ See for more details about the Schuman plan and the creation of the European Coal and Steel Community (ECSC) Van Meurs a.o. (2013: 42-48).
} 
and Steel Community, ECSC, based in Luxembourg. Six European countries took part in this first supranational organisation: France, Germany, Italy and the Benelux, Belgium, Netherlands and Luxembourg.

From a language political point of view it is remarkable that the Treaty was drawn up in French only, although French was not a national language in three of the participating countries. However, French was still the language of diplomacy in those days, at least in Western Europe.

The history of the European cooperation and integration does not stop here. The Treaty of Paris was followed by the better known Treaty of Rome (1957), which was the start of the European Economic Community, EEC, the predecessor of the EU. The four different language versions - French, German, Italian and Dutch - of this treaty are all seen as authentic. In 1992 the Treaty of Maastricht was signed, in which for the first time an article on European Culture was included in which respect for national and regional diversity is expressed, article $151^{8}$. As already said in the Treaty of Lisbon, signed in 2007 and entered into force on 1 December 2009, the Charter of Fundamental Rights is included whereby the Charter became legally binding. This Charter, which is not the same as the Charter for Regional and Minority Languages, which is a treaty of the Council of Europe that was signed in 1992, stipulates the respect of the EU for culture, religious and linguistic diversity in the Union.

\section{Working languages}

As seen already, the Treaty of Rome was drawn up in four languages, the national languages of the six constituent member states. This was a matter of principle, since the EU accepts all national languages as official languages of the Union: "The European Commission" maintains the policy that all EU citizens have the right to access all EU documents in the official language of the Commission, and should be able to write to the Commission and receive a response in their own language." 10 The European Parliament holds a similar point of view: "In the European Parliament, all official languages are equally important: all parliamentary documents are published in all the official languages of the European Union (EU) and all Members of the European Parlia-

\footnotetext{
${ }^{8}$ European Parliament Fact Sheet 2004. 4.17.0.

${ }^{9}$ The three most important EU institutions are; The European Commission, the European Parliament and the European Council, which is where the European leaders of government meet and take their decisions. The European Council should not be confused with the Council of Europe, described before. The Council of Europe is an independent institution.

${ }^{10}$ ec.europa.eu/languages/policy/language-policy/official_languages_en.htm
} 
ment (MEP) have the right to speak in the official language of their choice. It also ensures everyone is able to follow and access the Parliament's work." ${ }^{11}$ However, the most important, democratic reason to accept all national languages as official languages of the EU is that all citizens of the EU, whether they speak foreign languages or not, have the right to run for Parliament, or even the Commission: "The European Parliament differs from the other EU institutions in its obligation to ensure the highest possible degree of multilingualism. Every European citizen has the right to stand for election to the European Parliament. It would be unreasonable to require MEPs to have a perfect command of one of the more frequently used languages, such as French or English. The right of each Member to read and write parliamentary documents, follow debates and speak in his or her own language is expressly recognised in Parliament's Rules of Procedure."12 Being a representative of the people - a MEP or in full a Member of the European Parliament - is a function different from other jobs. Whereas one may set requirements for the fulfilment of a normal job, it is the democratic right of all citizens, whether they may have an education or not, to stand for election. Therefore MEPS cannot be required to have command of foreign languages.

This means that the EU has to make considerable cost for translation and interpretation. Today there are 24 official languages and 28 member states. The total costs for translation and interpretation amounts to more or less $€ 1.250$ billion per year, which is less than $1 \%$ percent of the total yearly budget and which is around $€ 2,-$ per European citizen per year ${ }^{13}$.

Two languages, that are official languages of countries of the EU, are not yet represented among the 24 official languages. The first one is Luxembourgish, the other one Turkish. Luxembourg now has three official languages. Luxembourgish is the everyday spoken language in Luxembourg, whereas French and German are merely administrative languages, although almost everybody in Luxembourg or at least a majority of the inhabitants has also a good command of these languages. However, till 1984 the government of Luxembourg never recognised Luxembourgish as one of the official national languages. Till that time only French and German were considered to be the official languages. So when Luxembourg signed the first European integrationist treaties there was no need neither a wish to include Luxembourgish. Later on the Luxembourg government never applied for recognition of the then most widely spoken official language of its country.

\footnotetext{
${ }^{11}$ Fact Sheet on the European Union/Language Policy.

${ }^{12}$ Multilingualism in the European Parliament.

${ }^{13}$ ec.europa.eu/dgd/translation/faq/indez_en.htm
} 
Turkish is a different case. Turkish is not only the language of Turkey but also the official language of the inhabitants of Northern Cyprus, officially part of the EU, but actually out of the scope of the EU. That is why there is no need to accept Turkish as one of the working languages of the European institutions, as long as the inhabitants of Northern Cyprus are not able to elect representatives for the European Parliament.

\section{Co-official languages}

However, there is even a more serious language problem within the European institutions and the European Union. Quite a few European citizens speak regional or minority languages; most of the time these speakers are bilingual and speak also one of the national languages of the EU. Since the EU only accepts the official national languages, it cannot accept these regional and minority languages as official languages of the Union as long as the national member states do not recognise these languages as official national languages.

The term minority language may be misleading. Some of the regional and minority languages are spoken by millions and millions of people. There are for instance more than 9 million native speakers of Catalan, whereas Hungarian is spoken by 14 million speakers, of which less than 10 million people live in Hungary, Finnish by 5.5 million, Estonian by 1.1 million and Maltese by 400.00 speakers only ${ }^{14}$.

The case of Catalan, the most widely spoken regional language in Europe, has been discussed in the European Parliament a few times without much success. A request in 2005 from the Spanish socialist government to accept and to regularize the linguistic situation as it is reflected in the 1978 Spanish constitution was more successful. The Spanish constitution recognizes autonomous communities, of which some have an 'official language of their own in addition to Castilian (Spanish) ${ }^{15}$. The Bureau of the European Parliament accepted this request of the Spanish government partly and from 2006 on Basque, Catalan and Galician are given the status of co-official language, which means that citizens may address the European institutions in Basque, Catalan, or Galician and will be answered in these languages ${ }^{16}$. However, it is the Spanish government which has to provide the European offices with a translation into one of the official languages of the EU and its again the Spanish government who has to take care of the translation of the answers into the regional languages. The costs of these translations are for the Spanish government ${ }^{17}$. Interpretation from but not into

\footnotetext{
${ }^{14}$ en.wikipedia.org/wiki/Languages_of_Europe

${ }^{15}$ Mercator bulletin 13/xii/2004.

${ }^{16}$ Mercator News June/July 2006.

${ }^{17}$ European Commission (2013). Frequently asked questions on language.
} 
Basque, Catalan/Valencian/Balearic and Galician is provided upon request for certain institutional formations with regional representatives ${ }^{18}$.

Two years later a request of the UK government to accept Welsh as a co-official language was also successful ${ }^{19}$. In 2009 Scottish Gaelic was granted co-official status as well and Michael Russel, cabinet secretary of state for education and lifelong learning was the first person ever to speak Scottish Gaelic in a European Council Meeting at 11 May 2010 2021.

\section{Working languages}

Although the EU accepts all national languages as working languages, this does not mean that in day to day practice European officials simply use each of the 24 official languages. For instance the European Commission conducts its daily work in three 'procedural' languages: English, French and German ${ }^{22}$. The same applies to the Permanent Representatives Committee, COREPER, the permanent committee of the 'ambassadors' of all the member states in which the usual negotiations and preparations of meetings of ministers and prime ministers take place. In the day to day work of the other institutions the same practice is used.

Although there is no official hierarchy within the three procedural languages, actually there is one. The daily press briefings of the European Commission are in French and English only. Even French is losing ground: "The trend in recent years has been towards a reduction in the number of documents drafted directly in French, particularly within the European Commission. While the European Union's multilingual regime is unchallenged in law, in practice the enlargement of 1 May 2004 brought about a major change of context that has led to increased use of certain preferred working languages, ${ }^{, 23}$ reports the French permanent representative to the European Union. These concerns led the French government to write a report, Le français dans les institutions européennes (February 2006), in which the French government stipulates the rights of French in all the institutions, even in informal meetings.

As a consequence and as a result of the burden of translation quite often documents are not translated in all languages anymore or at a later moment. This to the outrage of the speaker of the German Bundestag (House of Commons),

\footnotetext{
${ }^{18}$ European Commission (2013). Frequently asked questions on language.

${ }^{19}$ Welsh language in the EU.

${ }^{20}$ The Scottish Government/ Riaghtalas na h-Alba 11/05/2010: Gaelic spoken in Europe.

${ }^{21}$ See about the legal status of these co-official languages and the differences with official languages on the one hand and regional or minority languages at the other hand Milian-Massana (2008).

${ }^{22}$ European Commission (2013). Frequently asked questions on language.

${ }^{23}$ The French language in European institutions.
} 
Norbert Lammert who wrote a letter to the president of the European Commission in which he complained about the degradation of German on 12 April $2006^{24}$. He was seconded by the French Assemblee nationale and his own German deputy minister of foreign affairs, Günter Gloser: "The German government is stepping up its efforts to make German more prominent in the EU, demanding that EU documentation be translated into the language of Goethe- or else it will not attend meetings. "Germany has a right to have these documents in German," the deputy foreign minister, Günter Gloser, told German news agency DPA on Thursday (20 april). In a joint statement earlier this month, the German parliament and the French national assembly denounced the "unacceptable drift toward a monolingual system" dominated by English. Bundestag president Norbert Lammert wrote in a letter to European Commission president Jose Manuel Barroso that the German parliament would refuse to debate EU documents that were not printed in German." (Küchler 2006).

The German authorities have a point: although English is the language that is most widely spoken and understood by native speakers and second language speakers, it is German, which is the language with the greatest number of native speakers in Europe (Vasagar 2013) ${ }^{25}$. Nevertheless their plea for a more balanced approach is not very successful due to the international pressure of English and to the burden of translation. There is simply not enough time, money and opportunity to produce translations into all the official languages of the EU simultaneously.

However, this does not mean that the EU plans to give up its multitude of languages. In the European Commission list of frequently asked questions on languages one finds a question about this topic: "Does the EU plan to reduce the number of official languages?" The answer is clear: "No, because the current system is in place in the interest of democracy and transparency. No Member State is willing to relinquish its own language and candidate countries want to have theirs added to the list of official languages."26

So in this respect the EU remains an exception since other international organisations only work with a restricted number of working languages. The Council of Europe and the NATO as well as the International Criminal Court use English and French, the WTO and ILO French, English and Spanish, whereas the UN started with English and French only, but now also makes use of Arabic, Chinese, Spanish and Russian ${ }^{27}$. The OSCE uses five working languages, English, French, Italian, Russian and Spanish (Smeets 1999: 387).

\footnotetext{
${ }^{24}$ Presservice/Presseportal Deutscher Bundestag.

${ }^{25}$ See for more details also: Europeans and their languages. Special Eurobarometer 386, June

${ }^{26}$ European Commission (2013). Frequently asked questions on language.

${ }^{27}$ en.wikipedia.org/wiki/Working_language
} 2012. 
The main difference between these international organisations and the EU is that they do not represent citizens of the member states but the member states themselves. So there is no democratic right for citizens of the participating states to stand for election in the assemblies of these organisations.

\section{One language}

Although the official position of the EU is that there should be no discussion about the multi-language issue, in fact there is. Especially since translation and interpretation is costly, but this is not the only argument. Buitendijk and Hoogmoed (2004) for instance argue for one institutional language for the European Parliament, which is English, especially because of reasons of efficiency and because they expect a more lively debate and a better mutual understanding when everybody has to use the same language.

The Dutch linguist Riek Smeets, who wrote a report on Dutch language policy from a European perspective for the Nederlandse Taalunie, The Dutch Language Union, a supranational institution founded by the Dutch and the Flemish authorities that aims at defending, supporting and promoting the Dutch language and culture in the Low Countries and worldwide, recommended that the European governments should strive for a laissez faire policy with respect to the use of working languages in the European institutions. The Dutch and Flemish ministers accepted this recommendation nr. 11 and therewith implicitly gave up the rights of their own national language Dutch and at the same time accepted English as the most likely only remaining working language (Smeets 2001).

It are not only the Dutch who argue in favour of English as the working language for further European cooperation. The German president Joachim Gauck did the same in a speech on 22 February 2013 in which he appealed to the Brits to remain a member of the EU and within this context he said: "I am convinced that, in Europe, both can live side by side. The sense of being at home in your mother tongue, with all its poetry, as well as a workable English for all of life's situations and all age groups." Gauck's argument appeared even to be more ideological than practical when he argued that: "to encourage a greater sense of commonality, Europe needs a common language as well as encouraging multilingualism. ${ }^{28}$ However, he said this in German. ${ }^{29}$

Gauck's argument for a common language that may facilitate a common identity resembles Ernest Gellner's (1994) thesis that language plays an essential role in fostering nation building and in forming of common identities. Therefore

\footnotetext{
${ }^{28}$ Connolly (2013).

${ }^{29}$ Gauck (2013).
} 
quite some popular voices ${ }^{30}$ say that if we want a stable European Union, one should strive at least for a common language. Otherwise the European Union will remain a patchwork of languages and opposing national cultures and will fall into pieces sooner or later.

This opinion is actually more or less similar to the $18^{\text {th }}$ and $19^{\text {th }}$ century Romantic ideas of nationalism and the essential link between language and nation, as expressed by Herder and his followers (Dow 1999: 288), against which the French philosopher Ernest Renan argued already convincingly in 1882 in his Sorbonne lecture Qu'est-ce qu'une nation?, 'What is a nation', published in 1887. Renan supplies the example of Switzerland and shows how this nation knows to survive with a multitude of languages. Moreover the Swiss certainly share a national identity without speaking the same language. Eijsbouts (2014) supports Renan's critical reaction by referring to parallels with the linguistic situation in the USA, Russia and China, which are nations with a strong identity but without a common language.

\section{Language learning}

De Swaan $(2001)^{31}$ takes an opposite position. He does not argue in favour of one language for all the citizens of Europe neither in favour of a multilingual Europe, but he advocates the idea of multilingual citizens, who along their national language, which is not necessarily their mother tongue, also have a command of English. The multilingual citizen uses his national language for day to day activities and English for international contacts. So according to De Swaan, the ideal European citizens of the future will share a common language, English, for his contacts in Europe and with the rest of the world. Actually the situation is even more complicated. Quite often the mother tongue of the citizens is not the national language. In that case the ideal citizen needs to have a command of at least three languages: the mother tongue for day to day activities in the personal sphere and in informal day to day contacts, the national language when it comes to more official activities within the society of national citizens and English for international contacts.

A similar plea for a command of an international language was hold already by Novicov in the first decades of the last century (1903 \& 1911) (Van Heerikhuizen 2004). However, Novicov expected French to become the first

\footnotetext{
${ }^{30}$ See for instance: European Parliament News: 20120921 STO51986 (26-09-2012) and europe.idebate.org/debatabase/debates/international-affairs/house-believes-european-union-shouldadopt-single-working-language (a website that promotes debating among youngsters).

${ }^{31}$ In fact De Swaan does not discuss the linguistic situation of Europe, his interest is the global language relation.
} 
international language. He shared the common believe that using one common language in Europe finally would shape a European federation.

Actually what De Swaan implicitly suggests - that one should promote foreign language learning - is what the European Union does in the Lingua programme ${ }^{32}$, with one big difference. De Swaan would argue in favour of teaching and learning one international language, English, whereas the Lingua programme supports the teaching and learning of all European languages: "In the context of Lingua, language teaching covers the teaching and learning, as foreign languages, of all of the official Community languages as well as Irish and Luxembourgish. (...) Particular attention is paid to the development of skills in the less widely used and less taught official Community languages (the LWULT languages)." ${ }^{33}$ Actually the difference in approach is smaller than it looks like: English is the most widely taught foreign language in Europe ${ }^{34}$. Moreover two third of the Europeans think that English is one of the two most useful languages. Furthermore $67 \%$ of Europeans believe that English is much more likely to be considered useful for personal development than any other language ${ }^{35}$.

The budget of the Lingua programme looks impressive: 150 million euro ${ }^{36}$. However when one compares this budget to the budget for translation and interpretation one realises immediately what kind of priority language policy has in the EU.

At the Barcelona Summit of European leaders of government in 2002 a language objective in education was formulated ${ }^{37}$. In conclusion $44^{38}$ the European Council proposes: "to improve the mastery of basic skills by teaching at least two foreign languages from a very early age: establishment of a linguistic competence indicator in 2003." In the daily school practice this means that usually English is taught as one of these two foreign languages. However it must be stated that by far not all European countries already teach two foreign languages from an early age.

This initiative of the European Council was followed in 2003 by the European Commission, which published an 'Action Plan 2004-2006 for promoting

32 eacea.ec.europa.eu/static/en/overview/lingua_overview.htm

33 eacea.ec.europa.eu/static/en/overview/lingua_overview.htm

${ }^{34}$ Key data (2012: 11): "It [English] is by far the most taught foreign language in nearly all countries at all educational levels."

${ }^{35}$ Europeans and their languages. Eurobarometer 386 (2012: 69).

${ }^{36}$ European Commission Press Release IP-94-1097.

37 The Council of Europe preceded the EU-Summit with four years. September 1998 the Parliamentary Assembly of the Council accepted Recommendation 1383 on Linguistic Diversification. In this recommendation the Assembly promoted the idea of teaching and learning two foreign languages from an early age. One of these foreign languages could and most likely would be English. (Recommendation 1338 (1998)).

${ }^{38}$ Out of the 49 of part I of the Presidency Conclusion. 
language learning and linguistic diversity' in which the idea of teaching two foreign languages at an early age was developed ${ }^{39}$. Note that for the first time the phrasing 'linguistic diversity' appears here in an official document of the European Commission, which means that the Commission realized that in Europe the language problem is not only communicating at an international level but at the same time protecting of lesser used or even endangered languages, just as in the objective of the Lingua programme.

The emphasis on linguistic diversity became more prominent with the appointment of a European Commissioner for Education, Training, Culture and Multilingualism in 2004, the Czech Ján Figel'. He published in 2005 A new Framework Strategy for Multilingualism ${ }^{40}$, the first full-fledged communication of the European Commission about multilingualism ${ }^{41}$. However with linguistic diversity mainly the multitude of national languages of the EU is meant. The focus of this strategy is more on learning foreign languages to improve the economic changes for the citizens of Europe without giving up one's national language than on protecting regional and minority languages.

\section{Protests}

The interest for regional and minority languages, that culminated in the 1992 European Charter for Regional and Minority Languages did not come as a bolt from the blue. From the 1950's on there were protest in different European countries against the linguistic monopoly of the most prestigious language, that was usually also the standard language, or against what would be called linguistic genocide by a scholar such as Tove Skutnabb-Tangas (2000).

Many examples of these feelings of discontent and of the subsequent protests can be found in the recent history of Western Europe. Only a very few will be mentioned here. Even in a quiet country as the Netherlands there once were language riots. In the northern province of Friesland speakers of Frisian, although they were well -educated and thus bilingual, protested because of not being allowed to use their mother tongue Frisian in court. This led to a serious uproar on Friday 16 November 1951, a day that is now known in the history of Frisian as Kneppelfreed, 'club Friday'42. The public discussion that started then was the beginning of a successful legal process of recognition of Frisian in the Netherlands. Frisian was first recognised by the Dutch ratification of the European

\footnotetext{
${ }^{39}$ European Commission Communication (2003) 449.

${ }^{40}$ European Commission Communication (2005) 596.

${ }^{41}$ Europen Commission Press Release IP-05-1451.

${ }^{42}$ www.kneppelfreed.nl and Taalcanon: Fries.
} 
Charter for Regional and Minority Languages in $1998^{43}$. Finally in 2013 a Frisian language law was accepted by the Dutch parliament. According to this law Dutch and Frisian are now the two official languages of the province of Friesland $^{44}$

Spain, a country well known for its problems with minority languages during the Franco regime (1936-1975), has seen numerous protests by groups that aimed at regional autonomy or more. In 1959 the ETA was founded in the Basque country. The ETA, Euskadi Ta Askatasuna, 'Basque Homeland and Freedom', is now known a separatist organisation that does not reject violence. However it started as an organisation for the supporting and promotion of the Basque culture and language ${ }^{45}$. In Galicia also a revival of cultural activities came up in circles of language enthusiasts in the same 1950's, which gradually began to lead to political protest by the 1960's (Hourigan 2004: 83). The situation in Catalonia was more or less similar: "Concerns about the disappearance of Catalan as a language of scholarship began to emerge in the 50s and 60s and led to the establishment of language revival movements" (Hourigan 2004: 74).

In Italy, or better in the northern part of Italy at the Austrian border, in South Tyrol, there was a serious language conflict as well. Here the German speaking Italian citizens of Alto Adige/ Südtirol fought for more autonomy and for language rights. After unsuccessful mediation by the UN in 1960/61 heavy terrorist attacks took place. The debate lasted for almost ten years, till in 1969 a compromise was reached. However, it took another good twenty years before Austria and Italy were able to inform the UN in 1992 that the pending problem of Alto Adige/ Südtirol had come to an end ${ }^{46}$.

In Belgium, a country famous for its language wars between speakers of Flemish or Dutch and speakers of Walloon or French, the protests did not come from a minority ${ }^{47}$. In the 1950 s the Flemish speaking part of Belgium was not much smaller than the French speaking population, whereas now the Flemish or Dutch speaking group constitute a firm majority ${ }^{48}$. Furthermore the protest were not directed against the standard language, which is Dutch for the Flemish speaking group, but against the economic, social, educational and cultural supremacy of the most prestigious language in the country, French. These protests culminated in violent actions by Flemish students in Leuven/ Louvain, where French was the most prestigious and powerful language within the Roman

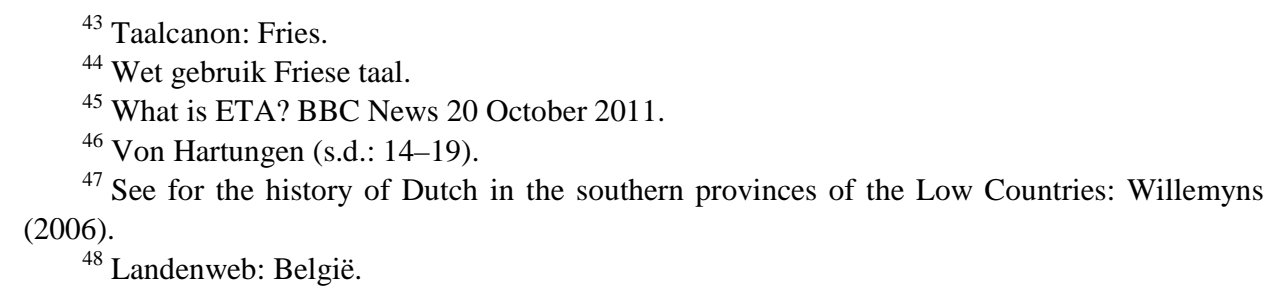


Catholic university, although the city of Leuven is in the centre of the Dutch speaking area of Belgium. The student revolt of 1968, which was a phenomenon that occurred throughout the whole of Europe, got a special language flavor in Leuven. Here the slogan of the students was: Leuven Vlaams-Walen buiten 'Leuven Flemish-Walloons out'. After riots of several weeks and the fall of the national government the Flemish students won. The bishops had to admit the defeat. The university of Leuven became completely Dutch speaking. For the French speaking community a new university was built Louvain-La-Neuve, at the other side of the language border ${ }^{49}$.

\section{Political initiatives}

The quarrels and protests mentioned so far are only a small part of the linguistic disputes of this period. Therefore a few politicians realized that something should be done to guarantee the rights of speakers of minority languages. Usually these advocates of linguistic minority rights were not politicians of the ruling groups, but representatives of disadvantaged minorities. The Council of Europe, the Strasbourg based organisation that considers itself as the guardian and promoter of democratic security, based on human rights, democracy and rule of law, was an excellent place to have heard this sound ${ }^{50}$.

As early as 1957 the Council of Europe accepted already a resolution with an appeal upon the governments of Europe to grant equal rights to speakers of regional and minority languages and to protect less prestigious languages.

The call to protect minority languages and their speakers was not restricted to Europe. In 1948 the General Assembly of the United Nations still skipped the word linguistic in the description of possible genocides when the Convention on the Prevention and Punishment of the Crime of genocide was brought to a vote ${ }^{51}$, a few years later in 1966 the United Nations accepted the International Covenant on Civil and Political Rights. Article 2.1 of this Covenant, accepted by 167 countries $^{52}$, reads: "Each State Party to the present Covenant undertakes to respect and to ensure to all individuals within its territory and subject to its jurisdiction the rights recognized in the present Covenant, without distinction of any kind, such as race, colour, sex, language, religion, political or other opinion,

\footnotetext{
${ }^{49}$ Kromhout (2002).

${ }^{50}$ For an extensive overview of all the initiatives taken by members of the Parliamentary Assembly of the Council of Europe and by Members of the European Parliament, see Hamans (2008).

${ }^{51}$ Linguistic genocide (Convention 1948).

${ }^{52}$ treaties.un.org/Pages/ViewDetails.aspx $?$ src=TREATY\&mtdsg_no=IV-4\&chapter=4\&lang=en\# EndDec (retrieved 1609-2014).
} 
national or social origin, property, birth or other status." Article 24.1 stipulates the right of children to be protected without any discrimination, that of language included. Article 26 says the same with respect to the equality of all persons before the law. Moreover article 14.3. states: "In the determination of any criminal charge against him, everyone shall be entitled to the following minimum guarantees, in full equality: (a) To be informed promptly and in detail in a language which he understands of the nature and cause of the charge against him". Finally article 27 is explicit about language rights of minorities: "In those States in which ethnic, religious or linguistic minorities exist, persons belonging to such minorities shall not be denied the right, in community with the other members of their group, to enjoy their own culture, to profess and practise their own religion, or to use their own language, ${ }^{, 53}$. This is still a very abstract and little concrete way to describe language rights and to defend and protect them, but it was a first legally binding step.

When entering the European Parliament, the parliamentary institution of the EU, after the first direct elections of the European Parliament in 1979, John Hume, a MEP from Northern Ireland and the later winner of the 1998 Nobel Peace Prize ${ }^{54}$, immediately proposed a Bill of Rights of the Regional Languages and Cultures of the [European] Community. Similar proposals and resolutions were put forward in for instance 1981, 1987 and $1994^{55}$.

As a result of the actions of both parliaments a European Bureau for Lesser Used Languages was founded in 1982. This bureau was based in Dublin and received financial support from the European Commission till 2010 ${ }^{56}$; it dealt with regional and minority languages all over Europe. At conferences and in reports one finds data about a manifold of RML's, Regional and Minority Languages, such as, to mention only a few, Alsatian, Basque, Breton, Catalan, Cornish, Finnish in Sweden, Frisian, Gaelic, German in Denmark, Friulian, Kashubian, Ladin, Mòcheno, Roma, Sami, Sorbian and Swedish in Finland. Remarkable is that EBLUL in 1982 used the term Lesser Used Languages, an apparently euphemistic term. Most likely the issue of minority rights was not as established as it is now.

Five years later the Mercator Network was founded, a network of five academic institutes, aimed at promoting research in the status and the use of regional and minority languages. Later on the network broadened its scope and now

\footnotetext{
${ }^{53}$ Covenant on Political and Civil Rights (1966).

${ }^{54}$ www.nobelprize.org/nobel_prizes/peace/laureates/1998/

${ }^{55}$ For (more) details see Hamans (2008).

${ }^{56}$ After EBLUL had to stop its activities because of lack of funding, the platform ELEN took over some of the activities of EBLUL, European Language Equality Network (see www.coe.int/t/dghl/ monitoring/minorities/6_Resources/PDF_FCNM_15th_Anniv_DHicks.pdf).Eurolang, originally EBLUL's news service continues its work for ELEN.
} 
also studies recent immigrant languages and language learning. The coordination of the very active network is in the hands of the Fryske Akademy, Frisian Academy, in Ljouwert/Leeuwarden in Friesland, Netherlands. The other partners are based in Catalonia, Hungary, Sweden and Wales. The network is financed by the European Commission ${ }^{57}$.

\section{The Charter}

In 1992 the Council of Europe accepted the European Charter for Regional and Minority Languages ${ }^{58}$, that after ratification by eight member states took effect from March 1998 on. At the moment 25 member states of the Council ratified the Charter already, whereas another eight signed it ${ }^{59}$. Some of them are supposed to ratify the charter soon, others, such as France, signed already long ago, but did not ratify it due to internal political or constitutional problems (Hamans 2008).

The aim of the charter is: "The Charter is a convention designed on the one hand to protect and promote regional and minority languages as a threatened aspect of Europe's cultural heritage and on the other hand to enable speakers of a regional or minority language to use it in private and public life. Its overriding purpose is cultural. It covers regional and minority languages, non-territorial languages ${ }^{60}$ and less widely used official languages ${ }^{61}$.

First and foremost, the Charter sets out the main objectives and principles that states undertake to apply to all regional or minority languages existing within their national territory.

Secondly, the Charter contains a series of concrete measures designed to facilitate and encourage the use of specific regional or minority languages in public life.

Within its scope are the languages traditionally used within a state's territory, but it does not cover those connected with recent migratory movements or dialects of the official language.

It is intended to ensure, as far as is reasonably possible, that regional or minority languages are used in education and in the media, to permit and encourage their use in legal and administrative contexts, in economic and social life, for cultural activities and in transfrontier exchanges." 62

\footnotetext{
${ }^{57}$ www.mercator-network.eu/mercator-network/

${ }^{58}$ For the full text of the charter see: conventions.coe.int/Treaty/en/Treaties/html/148.htm

${ }^{59} \mathrm{http} / / /$ www.coe.int/t/dg4/education/minlang/aboutcharter/default_en.asp

${ }^{60}$ For instance Yiddish or the languages of the Roma and Sinti.

${ }^{61}$ For instance Swedish in Finland.

${ }^{62}$ www.coe.int/t/dg4/education/minlang/aboutcharter/default_en.asp
} 
The Charter does not establish a list of European languages corresponding to the concept of regional or minority languages, the national authorities of the member states themselves have to list the languages they want to protect and promote according to the Charter.

The Charter "sets out the main principles and objectives upon which states must base their policies, legislation and practice, and which are regarded as providing the necessary framework for the preservation of the languages concerned" ${ }^{\prime \prime 3}$.

The Charter offers a variety of undertakings a national government may take to protect and promote the RML's used at their territory. However, there are eight fundamental principles and objectives that always should be respected. These are as follows:

- "Recognition of regional or minority languages as an expression of cultural wealth.

- Respect for the geographical area of each regional or minority language.

- The need for resolute action to promote such languages.

- The facilitation and/or encouragement of the use of such languages, in speech and writing, in public and private life.

- The provision of appropriate forms and means for the teaching and study of such languages at all appropriate stages.

- The promotion of relevant transnational exchanges.

- The prohibition of all forms of unjustified distinction, exclusion, restriction or preference relating to the use of a regional or minority language and intended to discourage or endanger its maintenance or development.

- The promotion by states of mutual understanding between all the country's linguistic groups". ${ }^{64}$

From what has been said before it must be clear that joining the Charter is not free of obligation. The Council checks whether member states follow the guide lines of the Charter by means of a monitoring process: "The European Charter for Regional or Minority Languages provides for a monitoring mechanism to evaluate how the Charter is applied in a State Party with a view to, where necessary, making recommendations for improvements in its legislation, policy and practice. The central element of the monitoring mechanism is a committee of independent experts" ${ }^{\prime 65}$ from the participating countries. Each country may delegate one expert. Some of the experts are linguists, others legal experts, quite a few former politicians.

\footnotetext{
${ }^{63}$ www.coe.int/t/dg4/education/minlang/aboutcharter/default_en.asp

${ }^{64}$ www.coe.int/t/dg4/education/minlang/aboutcharter/default_en.asp

${ }^{65}$ www.coe.int/t/dg4/education/minlang/aboutmonitoring/default_en.asp
} 
The monitoring cycle takes three years and includes reporting by the national authorities about their achievements, a visit on the spot by the experts, an extensive and detailed report by the committee and a discussion in the Council of Ministers. Although the outcome is only a recommendation and although the Council of Europe has no sanctions and means of coercion, the monitoring process is still a powerful weapon. Since the experts meet with the representatives of the minority groups and since all the reports are public, frequently a public debate arises as a consequence of one of the recommendations of the committee of experts. No government can resist public opinion.

So the committee of experts was able to draw attention to the poor (educational) situation in which Roma have to survive in Slovakia, to call on the Spanish government to take its own regulations seriously, to make suggestions to the Scandinavian governments for a still better protection of the languages of the speakers of the different Sami languages and to appeal to the Ukrainian government to come to terms with the speakers of Russian.

The Charter was followed by the Framework Convention for the Protection of National Minorities, also an initiative of the Council of Europe ${ }^{66}$. The scope of this Convention is much wider than that of the Charter. Language is only a part of the protection the convention aims at: "The Convention is the first legally binding multilateral instrument concerned with the protection of national minorities in general. Its aim is to protect the existence of national minorities within the respective territories of the Parties. The Convention seeks to promote the full and effective equality of national minorities by creating appropriate conditions enabling them to preserve and develop their culture and to retain their identity. The Convention sets out principles relating to persons belonging to national minorities in the sphere of public life, such as freedom of peaceful assembly, freedom of association, freedom of expression, freedom of thought, conscience and religion, and access to the media, as well as in the sphere of freedoms relating to language, education, transfrontier co-operation, etc. ${ }^{67} . "$

In 2013 the term 'endangered languages' emerged for the first time in the official papers of the EU, when the Corsican Green MEP François Alfonsi wrote a non-binding initiative report on endangered European languages and linguistic diversity in the European Union ${ }^{68}$. The report, that was accepted by the Parliament, calls upon the European Union and the member states to be more attentive to the extreme threat that many European languages, classified by Unesco ${ }^{69}$ as endangered, are experiencing.

\footnotetext{
${ }^{66}$ For the full text, see: conventions.coe.int/Treaty/en/Treaties/html/157.htm

${ }^{67}$ conventions.coe.int/Treaty/en/Summaries/Html/157.htm

${ }^{68}$ Report on endangered European languages (2013/2007(INI)).

${ }^{69}$ Unesco Redbook (1993).
} 
Aside from the Council of Europe and the EU, the OSCE, the Organisation for Security and Co-Operation in Europe, called for attention for the mostly Russian speaking minorities in Central Europe and their lack of linguistic recognition in the Oslo Recommendation Regarding the Linguistic Rights of National Minorities (1998). In this report the High Commissioner, the highest official of the OSCE, seeks to provide guidance to OSCE participating states on how best to ensure the linguistic rights of national minorities within their borders.

\section{Conclusion}

So far three aspects of language problems in the EU and Europe have been distinguished:

- the multitude of languages in the European institutions

- the lack of command of foreign languages among the peoples of Europe, which impedes mutual communication and trade

- the (dangerous) situation of marginal, minority and regional languages.

The first aspect has the full attention of the European authorities. The policy they implement is based on a principle: the principle of equal rights. Although the cost of translations and interpretation are relatively high, this policy is continued consistently.

The second problem recently received more attention, but in fact nothing has been done to implement the ideas which the leaders of Europe decided upon at the Barcelona summit in 1992. This is due to the fact that the EU has no competence of its own when it comes to education. However, since knowledge of foreign language is an economic asset one may expect that this aspect will become more prominent sooner or later.

The third area only recently emerged in the political arena of the EU.

Although Salverda (2007: 13) is completely right when he says that the European union lacks a clear, simple and coherent set of principles for a European language policy, the situation is less alarming than his wording suggests. Next to the EU there is the Council of Europe, a paper tiger in the eyes of the powerful. However, this institution formulated a coherent and well organized system of checking the actual state of endangered languages in the countries that ratified the Charter of Regional and Minority Languages.

However, as long as the focus in implicit and explicit language policy is concentrated on the problems of communicating within the European Institutions one cannot expect the citizens of Europe to understand the need of protecting linguistic diversity fully. 


\section{References}

Action Plan 2004-2006. Communication from the Commission to the Council, the European Parliament, the Economic and Social Committee and the Committee of the Regions - promoting language learning and linguistic diversity: an action plan 2004-2006 /* COM/2003/0449 final */. Brussels: European Commission. Also available at: eur-lex.europa.eu/legal-content/ EN/TXT/?uri=CELEX: 52003DC0449

Buitenweg, K. and S. Hoogmoed. 2004. "Een geheime agenda voor het Europees Parlement". In: van Heerikhuizen, A., van Montfrans, M., Naarden, B. and J. Herman Reestman. (eds.). Het Babylonische Europa, opstellen over veeltaligheid. Amsterdam: Amsterdam University Press. 309-319.

Dow, J.R. 1999. "Germany”. In: Fishman, J.A. (ed.) Handbook of language and ethnic identity. Oxford: Oxford University Press. 286-299.

Eijsbouts, T. 2006. "Europe's single and powerful amphibious model”. In: Kaddous, Ch. and A. Auer. (eds.) Les principes fondamentaux de la constitution européenne. Genève: Helbig and Lichterhahn. 83-90.

Eijsbouts, T. 2014. Rutte onaardig, onwaardig, schaamteloos. Lieden: HogendorpCentrum.

European Commission Communication. 2003 (449). Communication from the Commission to the Council, the European Parliament, the Economic and Social Committee and the Committee of the Regions - promoting language learning and linguistic diversity: an action plan 2004-2006 /* COM/2003/0449 final */. Brussels: European Commission. Also available at: eur-lex.europa. eu/legal-content/EN/TXT/?uri=CELEX: 52003DC0449

European Commission Communication. 2005 (596). Communication from the Commission to the Council, the European Parliament, the European Economic and Social Committee and the Committee of the Regions - a new framework strategy for multilingualism. /* COM/2005/0596 final */. Also available at: eur-lex.europa.eu/legal-content/EN/TXT/?uri=CELEX: 52005DC0596

Gellner, E. 1994. "On nationalism”. In: Smith, A. and J. Hutchinson. (eds.) Nationalism. New York: Oxford University Press. 57-62.

Hamans, C. 2008. "The minority language debate - the case of Yiddish in the Dutch language landscape”. Scripta Neophilologica Posnaniensia IX. 131-156.

Heerikhuizen, A. Van. 2004. "Woorden van Europa: Een vroeg sociologisch pleidooi voor een gemeenschappelijke taal". In: van Heerikhuizen, A., van Montfrans, M., Naarden, B. and J. Herman Reestman. (eds.). Het Babylonische Europa, opstellen over veeltaligheid. Amsterdam: Amsterdam University Press. 263-276.

Hourigan, N. 2004. Escaping the global village: media, language, and protest. Lanham, Maryland: Lexingtoon Books.

Key data on teaching languages at school 2012. Brussels: European Commission, Education, Audiovisual and Culture Executive Agency (EACEA P9 Eurydice and Policy Support). Also available at: eacea.ec.europa.eu/education/eurydice/documents/key_data_series/143EN.pdf

Meurs, W. van, de Bruin, R., Hoetink, C., van Leeuwen, K., Reijnen, C. and L. van de Grift. 2013. Europa in alle staten. Zestig jaar geschiedenis van de Europese integratie. Nijmegen: Van Tilt.

Milian-Massana, A. 2008. "Languages that are official in part of the territory of the Member States". In: Arzoz, A. (ed.). Respecting linguistic diversity in the European Union. Amsterdam/Philadelphia: John Benjamins.

Renan, E. 1887. Discours et conférences. Paris: Calmann Lévy. Also available at: archive.org/stream/ discoursetconfr00renagoog\#page/n9/mode/2up

Salverda, R. 2007. "De talen in ons leven”. In: Devoldere, L.E.A. and R. Salverda (eds.). Overeind in Babel. Talen in Europa. Rekkem: Ons Erfdeel. 7-14. 
Schütze, R. 2012. European constitutional law. Cambridge: Cambridge University Press. 121-148.

Skutnabb-Kangas, T. 2000. Linguistic genocide in education or worldwide diversity and human rights? Mahwah, NJ: Lawrence Erlbaum Associates.

Smeets, R. 1999. "Talen en taalpolitiek in de Europese Unie". In: van der Sijs, N. (ed.) Taaltrots. Amsterdam: Contact. 381-416.

Smeets, R. (2001). Naar een samenhangend beleid voor het Nederlands vanuit Europees perspectief. Den Haag: De Nederlandse Taalunie. See also the short summary of this report as accepted by the Council of Ministers of the Taalunie: taalunie.org/organisatie/raad-der-neder landse-letteren/verslagen/naar-samenhangend-taalbeleid-voor-nederlands-vanuit-europees-per spectief

Swaan, A. de. 2001. Words of the world: the global language system. Cambridge: Polity Press.

Teasdale, A. and T. Bainbridge. 2012 ${ }^{4}$. The Penguin companion to European Union. London: Penguin Books.

von Hartungen, Ch.H. (s.d.). A brief contemporary history of Alto Adige/Südtirol (1918-2002). Translated into English by Vivienne Frankell. Bolzano/Bozen: Parliament of the Autonomous Privince (sic!) of Bolzano/Bozen. Also at: www.landtag-bz.org/de/datenbanken-sammlungen/ broschueren.asp

Willemyns, R. assisted by W. Daniels. (ed.). 2004. Het verhaal van het Vlaams. De geschiedenis van het Nederlands in de Zuidelijke Nederlanden. Antwerp: WPG-Standaard.

\section{Web references}

Barcelona Summit. 2002. Barcelona European Council 15 and 16 March 2002, Presidency Conclusion (SN 100/1/02 REV 1): ec.europa.eu/investinresearch/pdf/download_en/Barcelona _european_council.pdf

Churchill, Sir W. 1946. Europa-Rede in der Universität Zürich am 19. September 1946: www.europarl.europa.eu/brussels/website/media/Basis/Geschichte/bis1950/Pdf/Churchill_Re de_Zuerich.pdf

Connolly, K. 2013. "German president: make English the language of the EU". The Guardian, 22 February 2013: www.theguardian.com/world/2013/feb/22/german-president-pleads-britainstay-eu?guni=Article: in\%20body\%20link

Consolidated Treaty of the Functioning of the European Union: www. consilium.europa.eu/docu ments/treaty-of-lisbon? lang=en

Council of Europe-Conseil de l'Europe: www.coe.int/en/web/about-us/who-we-are

Council of Europe-Conseil de l'Europe, history: www.coe.int/60 years/

Covenant of the Political and Civil Rights (1966): www.ohchr.org/en/professionalinterest/pages /ccpr.aspx

European Charter for Regional or Minority Languages: conventions.coe.int/Treaty/en/Treaties/ $\mathrm{html} / 148 . \mathrm{htm}$

www.coe.int/t/dg4/education/minlang/aboutcharter/default_en.asp www.coe.int/t/dg4/education/minlang/aboutmonitoring/default_en.asp

European Commission. 2013. Frequently asked questions on languages in Europe, IP/ 13/875 (26 September 2013): europa.eu/rapid/press-release_MEMO-13-825_en.htm

European Commission Language Policy: ec.europa.eu/languages/policy/language-policy/official_ languages_en.htm

European Commission Press Release IP-94-1097: europa.eu/rapid/press-release_IP-94-1097_en.htm

European Commission Press Release IP-05-1451: europa.eu/rapid/press-release_IP-05-1451_en.htm 
European Commission Translation: ec.europa.eu/dgs/translation/faq/index_en.htm

European Parliament Fact Sheet/ Cultural Policy: www.europarl.europa.eu/facts_2004/4_17_ 0_en.htm

European Parliament News 20120921 STO51986 (26-09-2012): www.europarl.europa.eu/news/en/ news-room/content/20120921STO51986/html/European-Day-of-Languages-An-EU-with-onlyone-language-would-be-a-catastrophe

Europeans and their languages. Special Eurobarometer 386 (June 2012): ec.europa.eu/public opinion/archives/ebs/ebs_386_en.pdf

Fact Sheet on the European Union/ Language Policy: www.europarl.europa.eu/aboutparliament/ en/displayFtu.html?ftuld=FTu_5.13.6.html

Framework Convention for the Protection of National Minorities: conventions.coe.int/Treaty/ en/Treaties/html/157.htm \& conventions.coe.int/Treaty/en/Summaries/Html/157.htm

Gauck, J. 2013. Europarede 22.02.2013: www.youtube.com/watch?v=YWT7hnQAW24

Key data on Teaching Languages at School 2012: eacea.ec.europa.eu/education/eurydice/documents/ key_data_series/143EN.pdf

Kneppelfreed: www.kneppelfreed.nl

Kromhout, B. 2002. "Walen buiten!" was niet eens correct Nederlands, maar een gallicisme. Historisch Nieuwsblad (2002/9): www.historischnieuwsblad.nl/nl/artikel/6000/walen-buiten-wasniet-eens-correct-nederlands-maar-een-gallicisme.html

Küchler, T. 2006. Berlin sees red over English language dominance in Brussels. EUobserver 21.04.06: euobserver.com/political/21405

Landenweb: België: www.landenweb.net/belgie/bevolking/

Languages of Europe: en.wikipedia.org/wiki/Languages_of_Europe

Le français dans les institutions européennes (2006) : www.rpfrance-ue.org/IMG/francais_dans_ les_institutions.pdf

Lingua programma: eacea.ec.europa.eu/static/en/overview/lingua_overview.htm

Linguistic genocide (Convention 1948): privatewww.essex.ac.uk/ patrickp/lhr/Linguistic\%20ge nocide.htm

Mercator Bulletin: www.ciemen.org/mercator/butlletins/60-46.htm

Mercator News: www.ciemen.org/mercator/notidetail.cfm?IDA=897\&lg=gb

Multilingualism in the European Parliament: www.europarl.europa.eu/aboutparliament/en/007e 69770f/Multilingualism.html www.europarl.europa.eu/pdf/multilinguisme/coc2014_en.pdf

Pressservice/Presseportal Deutscher Bundestag: presseservice.pressrelations.de/standard/result_ main.cfm?aktion=jour_pm\&r=229006\&quelle=0\&pfach=1\&n_firmanr_=109484\&sektor=pm $\&$ detail $=1$ www.pressrelations.de/new/standard/dereferrer.cfm?r=229006

Recommendation 1338 (1998): assembly.coe.int/Main.asp?link=/Documents/AdoptedText/ta98/ EREC1383.htm

Report on endangered European languages(2013/2007(INI)):www.europarl.europa.eu/sides/get Doc.do?pubRef=-//EP//TEXT+REPORT+A7-2013-0239+0+DOC+XML+V0//EN

Scottish Government: www.scotland.gov.uk/News/Releases/2010/05/12090248

Taalcanon: Fries: www.taalcanon.nl/vragen/is-het-fries-een-taal/

The French language in European institutions: www.diplomatie.gouv.fr/en/french-foreign-policy1/european-union/france-and-the-european-union/article/the-french-language-in-european

The Oslo Recommendations Regarding the Linguistic Rights of National Minorities (1998): www.osce.org/hcnm/67531

Unesco redbook of endangered languages in Europe (1993, updated 1999): http://www.helsinki. fi/ tasalmin/europe_report.html 
Vasagar, J. 2013. "German should be a working language of EU”. The Telegraph, 18 June 2013: www.telegraph.co.uk/news/worldnews/europe/germany/10128380/German-should-be-a-wor king-language-of-EU-says-Merkels-party.html

What is ETA? BBC New 20 October 2011: www.bbc.co.uk/news/world-europe-11183574

Welsh language in the EU: ec.europa.eu/unitedkingdom/about_us/office_in_wales/welsh_language_ en.htm

Wet gebruik Friese taal: wetten.overheid.n1/BWBR0034047/geldigheidsdatum_30-11-2014

Working Languages: en.wikipedia.org/wiki/Working_language 